following ten years. As a result of the May Report on Economy, the annual sum made available to the Commission was cut down by 50 per cent for the next five years. This cut has been met in two ways : first by reducing the provision of forest workers' holdings to the number absolutely necessary for the working of the forests, and, secondly, by stereotyping the annual planting programme at 20,000 acres or thereby, which will substantially reduce expenditure on acquisition of land. An expanding programme necessitates land acquisition on a large scale. Under a stabilised programme, acquisition can be limited to the replacement of the area actually planted. The reduction in area annually required works out at about 40,000 acres. These changes mean that the machine will take longer to arrive at its goal, but that it will not be thrown out of gear. No labour is to be paid off, and elasticity has been achieved partly by the distribution of the planting work all over the country and partly by the fact that the programme has been an expanding one.

\section{National Research Laboratories, Canada}

ON Aug. 10, the new National Research Laboratories of the National Research Council of Canada were officially opened in Ottawa by the Governor-General, the Earl of Bessborough. Among other speakers at the official opening were the Prime Minister of Canada, the Right Hon. R. B. Bennett, and Dr. H. M. Tory, the president of the National Research Council and the National Research Laboratories. A description of the building and the proposed organisation of departments and staff was given in NATURE of Jan. 4, 1930. The building is severely classic in style and closely follows the design of the architect's model reproduced in our article. It comprises four stories and basement, and encloses two large interior courtyards, which give ample light to all laboratory rooms overlooking them. Under each courtyard is an arched exhibition hall. There are three main divisions of research, namely, physics and engineering, biology and agriculture, and chemistry. There is also a division of research information which will be responsible for the publication of the Canadian Journal of Research, annual reports, technical reports, and bulletins. In the south-west wing is a series of industrial exhibits. Many delegates to the Imperial Economic Conference were present at the opening ceremony, and the Right Hon. Stanley Baldwin presented a number of portraits of eminent men of science which were given by Surgeon. Capt. Hanson.

\section{National Research Council of Canada}

THE Report of the National Research Council of Canada for the year 1930-31 states that although industry has been under a cloud, during the year the demand for scientific assistance addressed to the Council has increased greatly. There are now 29 research committees associated with the Council in the solution of scientific and technical problems which arise in industry, and the annual expenditure is a little more than 550,000 dollars. Five fellowships of 1200 dollars, 22 studentships of 1000 , and 35 bursaries of 800 dollars a year have been awarded, and 35 researches conducted in Canadian universities have been assisted during the year. From the summaries of the activities of the associated committees and of the reports on assisted researches, it is evident that Canada is building up a corps of research workers whose influence on the future of her industries is likely to be most important.

\section{New Mount Everest Expedition}

A NEW attempt to reach the summit of Mount Everest will be made in 1933 . The announcement of the expedition, which appeared in the Times of Sept. 3, is made by Admiral Sir William Goodenough and Brigadier-General C. G. Bruce on behalf of the Royal Geographical Society and the Alpine Club respectively. The last expedition was in 1924, when $\mathrm{Mr}$. G. L. Mallory and Mr. A. C. Irvine lost their lives within some two hundred feet of the summit, if they did not actually reach the top. On the same expedition, Col. E. F. Norton and Dr. T. H. Somervell climbed to 28,200 feet. The previous attempts were in 1922 , when a height of 27,300 feet was reached, and in 1921, when the expedition was a reconnaissance of the routes. Since 1924 the difficulty in renewing the work has been due to the unwillingness of Tibet to grant permission. Now, however, the Dalai Lama has given consent to a British expedition and arrangements are in active progress. The leader of the expedition will be Mr. H. Ruttledge, late of the Indian Civil Service, who has had considerable experience of mountain climbing in the Himalayas. The office of the expedition will be at the house of the Royal Geographical Society, South Kensington, S.W.7, and the secretary is Mr. J. M. Scott, who was a member of the British Air Route Expedition to Greenland.

\section{New Archæological Periodical}

THE new archæological publication Préhistoire, of which the first number has just been issued, has been planned on lines differing from those of any archæological periodical now running. Its contents will consist entirely of original memoirs, and it will include neither reviews of books nor current news; while in scope it will cover the archæology and art of the preand protohistoric periods, that is to say, from the earliest times up to the foundation of the great empires of antiquity. The articles will be descriptivethese dealing with the latest discoveries-statements of new theory, or syntheses taking a broad survey of facts. A special feature will be the illustrations, which in the case of each communication will be adequate to the requirements of the subject, and, in any event, more ample than could be given in the general run of archæological periodicals. It is hoped that the ampler space and fuller illustration which will be available, will make it possible to include in Préhistoire studies of which the publication has been impossible up to now owing to their requirements in these respects. The new journal is edited by $M$. Raymond Lantier with an international editorial committee, which includes, among others, Comte Bégouen, the Abbé Breuil, Mr. Miles Burkitt, Prof. Bosch Gimpera, Prof. H. Obermaier, and Dr. O. Menghin. The first issue contains contributions by

$$
\text { No. 3281, Vor. 130] }
$$


Dr. Henri Martin on the Solutrian sculpture of Roc, Prof. H. Obermaier on the late Magdalenian art of the Grotte du 'Pendo', near Santander, and a long and very fully illustrated study by Dr. R. Forrer of the prehistoric ritual chariot and its survivals in historic times (see NaTuRE of Sept. 10, p. 404). Not only are the illustrations of each article ample, but they are also of a high quality. The price of Part 1 is $125 \mathrm{fr}$., but owing to the fact that the size of the parts will be variable, the price is not fixed. The annual subscription, however, is $250 \mathrm{fr}$. The publishers are Librairie Ermest Leroux, Paris.

\section{Prof. J. W. Gregory}

Follownag the obituary notice of Prof. J. W. Gregory by Sir John S. Flett (NATURE, June 25, p. 930) and the letter of appreciation by Prof. Bailey Willis (NATURe, Aug. 27, p. 310) we have just received a copy of an appreciation by Mr. F. Chapman, palæontologist to the Commonwealth of Australia, who was a lifelong friend of Prof. Gregory, published in the Melbourne Age for July 16. Much of Mr. Chapman's testimony is naturally concerned with Prof. Gregory's activities during the short period (1900-4) when he was professor of geology and mineralogy in the University of Melbourne. Victoria offered many fascinating geological problems ready to hand, and Prof. Gregory took advantage of these for a thorough training of his students in field work. One of his expeditions with a party of students to Central Australia resulted in his writing one of the finest geological essays, "The Dead Heart of Australia".

\section{Prehistoric Persia}

SHобLD subsequent investigation confirm the tentative attribution of a date contemporary with Susa I. to the Stratum I. in the mound now under excavation by the American Institute of Persian Art and Archæology at Damghan in northern Persia, the discovery fully justifies the claim for interest and importance made by Dr. Arthur Upham Pope in his letter to the Times of Sept. 12. He states that Dr. Erich Schmidt, field director of the expedition, has found in that stratum beautiful hand-made pottery and copper implements upon which he bases his suggested dating. He regards the lowest levels of the mound upon which the expedition is now engaged as coming very close to the fourth millennium B.c. Further evidence of this extension of the early painted pottery culture will be awaited eagerly. The important structure revealed in Stratum III., dating from about 2000 B.c., is of exceptional interest, not only on account of the singularly rich treasure of objects of high artistic merit in gold, silver, copper, and semi-precious stone, but also for the remarkable burial of a dancing girl which was found in one corner of the building. The body was laid out in dancing pose, with silver rings on the fingers, copper rings in the ears, long coiled armlets, a necklace of effigies of turtles in lapis and silver and a little copper lion, silver tubes, lapis beads, and other objects and ornaments in metal and stone. The mere catalogue of the finds calls up an intriguing picture of the magnificence of this early eastern court, of which, how- ever, the significance will be much enhanced when something more is known of its cultural and artistic affinities.

\section{Mohenjo-Daro Ideographs}

A BoLD and entirely speculative attempt to arrive at the meaning of the pictographic designs on the seals found at Mohenjo-Daro, in the valley of the Indus, is made by Sir Flinders Petrie in the course of a notice of the recently published account of the excavations on this site by Sir John Marshall, which appears in Ancient Egypt, 1932, pt. 2. Sir Flinders Petrie justifies his method of attacking the problem by taking the ideographic signs in their primary sense of 'pictures' expressive of ideas, on the grounds, first, that being engraved on stone they escaped transformation and retained their original detail, thus being comparable with the ideographic method of Egypt; and secondly, that the study of official titles and the method of writing them in Egypt has supplied parallels to what may be discerned in India. Thus the recurrence of a number of strokes suggests that parallel to an Egyptian 'Home of Four ', ' Five Men', and the like, we have a 'Hall of Four', 'Hall of Six', etc., pointing to a system of naming officials by the number holding office, like the Duumviri, Decemviri, etc., of ancient Italy. There is evidence for this method in Cappadocia. Another set of signs consists of wheels with six or four spokes, that is, chariots and wagons, signifying transport. 'Timber', 'water supply', ' an army ', 'game ', or 'hunting' are meanings suggested for other symbols, which, in combination with other signs suggesting authority, are interpreted as the designation of officials connected with departments of State ; thus, ' Officials of the Registry of Chariots'. Nearly one-half of a hundred symbols are interpreted tentatively on the presumption that they are certainly ideographic signs such as lie at the base of Egyptian, Sumerian, and Chinese writing, but at so early a stage that the forms can mostly be recognised.

\section{The 'Historical Society of Science', 1841}

In Isis for July 1932, Mr. H. W. Dickinson gives an account of the Historical Society of Science founded in London in 1840 by J. O. Halliwell and Thomas Wright. Halliwell, who was born in Chelsea on June 21, 1820, and died near Brighton on Jan. 3, 1889, was a most remarkable man, and even as a boy had a passion for collecting MSS. $\mathrm{He}$ matriculated from Trinity College, Cambridge, in 1837, and before he was twenty years old had written a life of Samuel Morland and edited Sir John Mandeville's "Travels". In 1839 he was elected F.S.A. and F.R.S. The prospectus of the short-lived society for the study of the history of science said that its object was " to render materials for the history of the Sciences accessible to the general reader, by the publication of manuscripts, or the reprinting of very rare works connected with their origin and progress in this country and abroad ". The Duke of Sussex became the president of the Society, and on the council were de Morgan, Palgrave, Baden Powell, Gardner Wilkinson, Prof. Robert Willis, and others. But though its start was an

$$
\text { No. 3281, VoL. 130] }
$$

